\title{
Community Health course load before clerkship in Brazilian medical schools
}

\author{
Carga horária de saúde coletiva antes do internato em escolas médicas brasileiras
}

\author{
Sofia Romay Oliveira' ${ }^{10}$ | sromay10@gmail.com \\ Athos Paulo Santos Martini' (D) athosmartini@gmail.com \\ Suely Grosseman ${ }^{1,2}$ (D) sgrosseman@gmail.com
}

\begin{abstract}
Introduction: The limits of the Community Health $(\mathrm{CH})$ course load $(\mathrm{CL})$ before medical clerkship $(\mathrm{MC})$ in undergraduate medical courses are not defined neither in the National Curriculum Guidelines nor in other documents, and have not been investigated in a comprehensive way in national studies.

Objective: To analyze the community health course load before clerkship in Brazilian medical schools.

Method: Cross-sectional study of schools acknowledged by the Ministry of Education, which started activities until December 31, 2017. The sites of the 323 existing schools were accessed and the schools that had their curricula available in the internet with details of the $\mathrm{CH} C \mathrm{CL}$ before $\mathrm{MC}$ were included. The variables were school geographic region and administration type, medical course $\mathrm{CL}$ and $\mathrm{CH} C L$ before $\mathrm{MC}$, also including epidemiology, biostatistics and occupational health course loads. Data were analyzed using descriptive statistics, Pearson chi-square $\left(X^{2}\right)$ for categorical variables and Mann-Whitney-U $(U)$ and Kruskal Wallis $X^{2}$ tests for continuous variables.

Results: Out of 323 existing medical schools, 222 were included (68.7\%). Among the included schools, 83 were tuition-free (37.4\%) and 139 were not (62.6\%). The median of the CH CL before MC was 440.0 hours $\left(P_{25-75}=300.0-640.0\right)$, equivalent to $5.4 \%\left(P_{25-75}=3.5-7.8\right)$ of the medical course $\mathrm{CL}$. The median of the $\mathrm{CH} C L$ before $\mathrm{MC}$ in hours in private and municipal schools was, respectively, $480.0\left(\mathrm{P}_{25-75}=330.7-679.2\right)$ and $576.0\left(\mathrm{P}_{25-75}=\right.$ $360.0-766.0)$, and of state and federal schools, respectively, $337.0\left(P_{25-75}=281.2-524.2\right)$ and $370.0\left(P_{25-75}=300.0-480.0\right), X 2(3)=11.48, p=.009$. The median of the total CH CL in non-tuition-free schools was 500.0 hours $\left(P_{25-75}=336.0-690.0\right)$ and in the tuition-free schools, it was 364.0 hours $\left(P_{25-75}=285.0-504.0\right), U=4.259 .0, z=-3.26, p=.001$. The median of epidemiology and biostatistics $C L$ in hours before $M C$ in the 124 schools was $88.0\left(P_{25-75}=60.0\right.$ - 120.0), whereas the occupational health $C L$ in 63 schools was $40.0\left(P_{25-75}=33.0-60.0\right)$.
\end{abstract}

Conclusions: The CH CL before clerkship varies widely, being higher in non-tuition-free medical schools.

Keywords: Medical Education; Curriculum; Public Health; Course Load; Community Health.

\section{RESUMO}

Introdução: Os limites da carga horária (CH) de saúde coletiva (SC) antes do internato (Al) não estão definidos nas Diretrizes Curriculares Nacionais, nem em outros documentos, e não foram investigados de forma abrangente em estudos nacionais.

Objetivo: Analisar a CH de SC Al em escolas médicas (EM) brasileiras.

Método: Estudo transversal, com escolas reconhecidas pelo Ministério da Educação que iniciaram as atividades até 31 de dezembro de 2017 . Os sites das 323 escolas existentes foram consultados, e foram incluídas aquelas que disponibilizavam seus currículos na internet com detalhamento de CH de SC Al. As variáveis foram região geográfica e administração da escola, CH do curso de medicina e CH de SC Al, incluindo também as CH de epidemiologia, bioestatística e saúde do trabalhador. Os dados foram analisados usando-se estatística descritiva, teste de qui-quadrado $\left(X^{2}\right)$ de Pearson para variáveis categóricas e testes Mann-Whitney-U (U) e X² de Kruskal-Wallis para variáveis contínuas.

Resultados: Foram incluídas 222 das 323 EM existentes (68,7\%), sendo 83 gratuitas (37,4\%) e 139 não gratuitas (62,6\%). A mediana da CH total de SC Al foi de 440,0 horas ( $\left.P_{25-75}=300,0-640,0\right)$, equivalente a 5,4\% $\left(P_{25-75}=3,5-7,8\right)$ da CH total do curso. A mediana da CH de SC Al em horas das escolas privadas e municipais foi de, respectivamente, $480,0\left(P_{25-75}=330,7-679,2\right)$ e 576,0 $\left(P_{25-75}=360,0-766,0\right)$; no caso das estaduais e federais, a mediana foi de, respectivamente, 337,0 ( $\left.P_{25-75}=281,2-524,2\right)$ e 370,0 $\left(P_{25-75}=300,0-480,0\right), X^{2}(3)=11,48, p=0,009$. As escolas não gratuitas tiveram mediana de $\mathrm{CH}$ total de SC de 500,0 horas $\left(P_{25-75}=336,0-690,0\right)$ e as gratuitas de 364,0 horas $\left(P_{25-75}=285,0-504,0\right), U=4.259,0, z=-3,26, p=0,001$. A mediana da CH, em horas, de epidemiologia e bioestatística Al entre 124 escolas foi de $88,0\left(P_{25-75}=60,0-120,0\right)$ e de saúde do trabalhador entre 63 foi de 40,0 $\left(P_{25-75}=33,0-60,0\right)$.

Conclusões: A CH de SC Al apresenta grande variação, sendo maior em escolas não gratuitas.

Palavras-chave: Educação Médica; Currículo; Saúde Pública; Carga Horária; Saúde Coletiva.

1 Universidade Federal de Santa Catarina, Florianópolis, Santa Catarina, Brasil.

2 Faculdades Pequeno Príncipe, Curitiba, Paraná, Brasil.

Chief Editor: Daniela Chiesa

Associate Editor: Pedro Tadao Hamamoto Filho

Received on 07/17/20; Accepted on 12/17/20.

Evaluated by the double blind review process. 


\section{INTRODUCTION}

Universities influence and are influenced by the communities in which they operate. The trained professionals are agents who share the knowledge generated in higher education with the population who receive their care'.

The relationship between medical education and the current health system is not different. The relevance of social determinants in the health-disease process has gained strength throughout the $20^{\text {th }}$ century, guiding the study of Social Sciences in the Public Health area ${ }^{2}$. The Health Reform movement started in Brazil in the beginning of the 1970s, aiming at a health policy that considered the community and its context. This movement culminated in the political, governmental and private groups agreement for the establishment of a Unified Health System (SUS, Sistema Único de Saúde), with universal, equal and free access to health, valuing collective care as an inseparable aspect of individual health, made official in the Federal Constitution of 1988 and in subsequent regulations needed for its implementation. ${ }^{3}$

Concomitantly, since the 1950s, there have been initial discussions regarding the medical curriculum and the teaching process ${ }^{4}$, which were intensified since the 1980s. It became clear that more professionals were required to competently work with the new health system being structured in its different levels of care. The transformation in the training offered by medical schools (MS) was considered as one of the most effective means to initiate changes regarding the future doctors and, therefore, in the way they worked in the health system ${ }^{5}$.

The transformation of the view on public health and of its representation in undergraduate medical curriculum also occurred in all continents where public health education was covered during medical school. Countries such as Canada, ${ }^{6,7}$, China $^{8}$, Spain ${ }^{9}$, Australia ${ }^{10}$, United Kingdom ${ }^{11,12}$ and Ghana ${ }^{13}$ are some examples.

In Brazil, in 2001, the National Curriculum Guidelines (DCN, Diretrizes Curriculares Nacionais) for undergraduate medical courses were developed, so that medical education was aligned with the SUS and the population needs and provided the training of doctors who were competent "to work (...) in the health-disease process" in all levels of care ${ }^{14}$. These DCN were developed based on a comprehensive MS assessment and further educators, health professionals and government discussions for shared decision-making ${ }^{14}$. The encouragement towards a general practitioner training, with practices including primary care settings and the development competencies related to public health stood out as a differential in relation to the existing curricula until then, which were predominantly aimed at medical specialties and with practices in hospitals. After 13 years, the DCN were restructured so that medical education would respond "to the new challenges of contemporary societies" adequately encompassing primary health care and valuing the training aligned with the SUS". In this new version, what was already covered in the previous DCN was reinforced and medical training was approached in three axes: health care, health management and health education ${ }^{15}$.

The DCN also establish a minimum course load $(\mathrm{CH})$ of 7,200 hours for medical courses ${ }^{15}$ and clerkship percentages in relation to the course load and areas of knowledge considered essential. However, and even to provide greater flexibility to schools regarding curricular planning, they do not suggest course loads limits for contents before clerkship. If, on the one hand, not having the limits for the areas of knowledge and contents before clerkship represents a possibility of a greater freedom to the curriculum planning in each school, on the other hand, this may result in a great variation in the $C L$ of each area, depending on the choices of managers and teachers. In this scenario, as stated by Lima-Gonçalves, despite the fundamental importance of the course load in the curricular structure, the decision of the $C L$ to be reserved for each discipline has often been carried out as a "bargaining chip" in the creation of curricula and can result in insufficient or excessive $\mathrm{CL}$ in certain areas ${ }^{16}$.

Regarding the teaching of Community Health $(\mathrm{CH})$, although both $\mathrm{DCN}^{14,15}$ versions recognize the importance of learning it in primary care practice settings, not all MS have been able to carry it out comprehensively. Also, as each MS can consider the theoretical and practical $\mathrm{CL}$ to be assigned to $\mathrm{CH}$ in its curriculum in different manners, the current $\mathrm{CH}$ CL limits in medical curricula need to be known.

The medical course at the Federal University of Santa Catarina (UFSC) changed its curriculum in 2003 to meet the recommendations of the DCN. In 2018, its curriculum contained a total $\mathrm{CL}$ of 7,670.0 hours, with a module called "Health and Society" aimed at $\mathrm{CH}$, taught from the first to the eighth semester of the course (before clerkship). The total module CL comprised 480.0 hours (6.2\% of the total curriculum $\mathrm{CL}$ ), with a total theoretical CL CH of 240.0 hours, which included 90.0 hours of epidemiology and biostatistics (EB) and 30.0 hours of occupational health $(\mathrm{OH})$, and with a total practice $\mathrm{CL}$ of 240.0 hours, carried out in primary health care settings, called community interaction. During the clerkship, the $\mathrm{CHCL}$ was of 736.0 hours. Therefore, the total $\mathrm{CHCL}$ at this university was of $1,094.0$ hours, corresponding to $14.3 \%$ of the total curriculum $\mathrm{CL}$. Aiming to assess the adequacy of this $\mathrm{CL}$, we searched for articles on the limits of $\mathrm{CH}$ CL before clerkship in Brazilian MS, which provided comparisons with national limits. However, we did not find comprehensive national studies. Therefore, the research question emerged: 
- What are the limits of $\mathrm{CH} \mathrm{CL}$ before-clerkship in Brazilian medical schools?

To answer this question, the objective of this study was to analyze the $\mathrm{CH}$ CL before clerkship in Brazilian medical schools.

\section{METHOD}

\section{Design and ethical principles}

This study was cross-sectional and descriptive. The research project was not submitted to the Research Ethics Committee because the data are secondary and of public domain, available on the internet.

\section{Study universe and sample}

The universe comprised all current 323 Brazilian MS until September 2018, acknowledged by the Ministry of Education (MEC) and listed on the e-MEC page at http://emec.mec.gov. $\mathrm{br}^{17}$. The websites of all existing schools were accessed and the criteria for their inclusion were: having started academic activities registered with e-MEC before December 31, 2017, having a curricular matrix or political-pedagogical project (PPP), also called Course Policy Project, available on the internet and containing information about the $\mathrm{CHCL}$ in the course.

\section{Data collection}

The data were collected between March and September 2018.

After consulting the e-MEC page on the website http: //emec.mec.gov.br ${ }^{17}$, the official website of each institution was accessed from this website, searching for the curriculum matrix and/or the PPP. When these documents were not available, a search for the university's website was carried out in the Internet, through Google', using the search key: ("university name") AND ("medicine") AND ("curricular matrix" OR "Political-Pedagogical Project" OR "Course Policy Project"). When available, the learning programs/teaching plans, their key-points, content and CL were analyzed, to confirm that the entire $\mathrm{CL}$ was aimed at $\mathrm{CH}$ and to differentiate the theoretical from the practical load.

To define modules and disciplines to be included as $\mathrm{CH}$, the UFSC's CH curriculum was used as basis: Health Education, Epidemiology and Biostatistics, Public Health Policies, Family and Community Medicine, Service Planning, Management and Evaluation, Occupational Health and Health Programs. Modules, disciplines and contents related to $\mathrm{CH}$ with names different from the previous ones were also included when they addressed SUS principles and operation, primary care attributes in health, public management, health information systems, biostatistics, health planning and occupational health.
This set integrates more contents than those included by some authors. Oliveira et al. ${ }^{18}$, for instance, do not include Statistics and Occupational Health, despite the importance of statistical analysis in population studies related to $\mathrm{CH}$ and the relevance of occupational health in the context of communityic health, which was confirmed by Resolution 1,488/98 of the Brazilian Federal Council of Medicine (CFM, Conselho Federal de Medicina) ${ }^{19}$, which provides specific standards for all doctors who provide care to the worker.

Although the Social and Human Sciences were considered relevant and essential for $\mathrm{CH}$, their contents were not included and accounted for in this study, because they are more often taught separately from public/community health and taught by departments in other areas of knowledge, such as Anthropology and Sociology.

The variables included were: geographic region and school administration, total medical course $\mathrm{CL}$, total compulsory $\mathrm{CH} \mathrm{CL}$ before clerkship, with its theoretical and practical $\mathrm{CL}$ (including activities carried out in the community, such as teaching-service interaction), $\mathrm{EB} C \mathrm{CL}$ and $\mathrm{OH} \mathrm{CL}$.

Despite being included in the total content of $\mathrm{CH}$, the $\mathrm{EB}$ and $\mathrm{OH} \mathrm{CLs}$ were individualized, for better understanding of their limits.

The CLs were standardized as "clock/hours", corresponding to an actual 60-minute hour. When the school specified that the class duration was different from the clock/hour, that time was calculated for the corresponding time in an actual hour. Before the conversion, some schools had 1 hour / class corresponding to 60, 50 or 45 actual minutes.

\section{Data analysis}

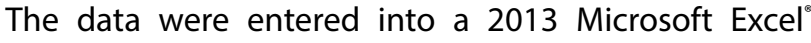
software database.

The analysis was performed using descriptive statistics, with absolute and relative frequency for categorical variables and measures of central tendency for continuous variables. The normality of continuous variables distribution was assessed using the Kolmogorov-Smirnov test, with the distribution being considered normal when $p \geq .05$. The central tendency measures for variables with normal distribution comprised the mean and standard deviation, and the measures for variables with non-normal distribution comprised the median and the $25^{\text {th }}$ and $75^{\text {th }}$ percentiles $\left(P_{25-75}\right)$. In order to provide comparisons with other studies, in the case of non-normal distribution, the mean and standard-deviation (SD) were also be provided.

Pearson's Chi-square test $\left(\mathrm{X}^{2}\right)$ for categorical variables and Mann-Whitney-U test $(U)$ and Kruskal Wallis $X^{2}$ for continuous variables were used to analyze differences between groups.

In addition to the individualized analysis of the school 
administration type, this category was grouped in tuition status, with tuition-free schools including federal and state schools and non-tuition-free schools including private and municipal schools.

The significance level was set at $p<.05$.

\section{RESULTS}

Table 1 shows the distribution of schools included and not included, by geographic region, administration type and tuition status. It can be observed that 222 of the 323 existing MS (68.7\%) were included. There was no difference between included and not included schools by administration type and tuition status inside each region. Also, the number of private and non-tuitionfree schools in Brazil is greater than that of tuition-free schools (63.5\%). The Southeast and South regions have the highest proportion of private and non-tuition-free schools in relation to the total number of schools in each of these regions $(64.2 \%$ and $77.8 \%$, respectively). The other regions have a more balanced proportion between tuition-free and non-tuition-free schools.
Table 2 shows the total course $\mathrm{CL}$, the $\mathrm{CHCL}$ before clerkship, as well as the percentage of the latter in relation to the $\mathrm{CL}$ of the course by geographic region, administration type and tuition status. As it can be observed, there was no difference in the $\mathrm{CH} C \mathrm{CL}$ before clerkship and its percentage in relation to the $\mathrm{CL}$ of the course by geographic region, but both were higher in non-tuition-free schools. The CH CL mean before clerkship was $487.0(\mathrm{SD}=249.3)$ and its percentage in relation to the $\mathrm{CL}$ of the course was $5.9 \%(\mathrm{SD}=3.0$ ).

Table 3 shows the theoretical and practical CHCLs before clerkship among schools that provided these data and the total $\mathrm{CH} \mathrm{CL}$ of schools which only provided the $\mathrm{CH} C L$ without discriminating the theoretical and practical $\mathrm{CL}$, by geographic region, administration type and tuition status. As it can be observed, in the North region, the theoretical $\mathrm{CH}$ CL before clerkship was higher among 9 of the 20 schools that provided this data. Among the 124 schools that did not discriminate whether the $\mathrm{CH} \mathrm{CL}$ before clerkship was theoretical and/or practical, the $\mathrm{CH}$ was higher in those that were non-tuition-free.

Table 1. Distribution of all medical schools acknowledged by MEC and active until December 31, 2017, by inclusion in the study, geographic region, administration type and tuition status.

\begin{tabular}{|c|c|c|c|c|c|c|c|c|c|c|}
\hline \multicolumn{4}{|c|}{ School characteristics } & \multicolumn{4}{|c|}{ Administration $(A)$} & \multicolumn{3}{|c|}{ Tuition-free (TF) } \\
\hline Geographic region & & & on (I) & Private & State & Municipal & Federal & Yes & No & Total \\
\hline \multirow{7}{*}{ North $^{a, b}$} & \multirow{7}{*}{$\mathbf{I}$} & \multirow{3}{*}{ Yes } & $\mathrm{n}$ & 8 & 4 & 1 & 7 & 11 & 9 & 20 \\
\hline & & & (\% A and TF) & $(66.7)$ & (100.0) & $(100.0)$ & (77.8) & (84.6) & (69.2) & (76.9) \\
\hline & & & (\%Total) & $(30.8)$ & $(15.4)$ & (3.8) & $(26.9)$ & $(42.3)$ & $(34.6)$ & (76.9) \\
\hline & & \multirow{2}{*}{ No } & (\% A and TF) & (33.3) & - & - & $(22.2)$ & (15.4) & (30.8) & $(23.1)$ \\
\hline & & & (\%Total) & $(15.4)$ & - & - & (7.7) & (7.7) & $(15.4)$ & $(23.1)$ \\
\hline & & \multirow{2}{*}{ Total } & $\mathrm{n}$ & 12 & 4 & 1 & 9 & 13 & 13 & 26 \\
\hline & & & $(\% \mathrm{I})$ & $(46.2)$ & $(15.4)$ & (3.8) & (34.6) & $(50.0)$ & $(50.0)$ & $(100.0)$ \\
\hline \multirow{9}{*}{ Northeast ${ }^{c, d}$} & \multirow{7}{*}{ I } & \multirow{3}{*}{ Yes } & $(\% \mathrm{I})$ & $(52.2)$ & (13.0) & - & (34.8) & $(47.8)$ & $(52.2)$ & (100.0) \\
\hline & & & (\% A and TF) & $(66.7)$ & $(46.2)$ & - & (57.1) & (53.7) & (66.7) & (59.7) \\
\hline & & & (\%Total) & $(31.2)$ & (7.8) & - & $(20.8)$ & (28.6) & $(31.2)$ & (59.7) \\
\hline & & \multirow{4}{*}{ No } & $\mathrm{n}$ & 12 & 7 & - & 12 & 19 & 12 & 31 \\
\hline & & & $(\% \mathrm{I})$ & $(38.7)$ & $(22.6)$ & - & (38.7) & (61.3) & (38.7) & (100.0) \\
\hline & & & (\% A and TF) & (33.3) & $(53.8)$ & - & (42.9) & $(46.3)$ & (33.3) & (40.3) \\
\hline & & & (\%Total) & $(15.6)$ & (9.1) & - & (15.6) & $(24.7)$ & (15.6) & (40.3) \\
\hline & \multirow{2}{*}{\multicolumn{2}{|c|}{ Total }} & $\mathrm{n}$ & 36 & 13 & - & 28 & 41 & 36 & 77 \\
\hline & & & $(\% \mathrm{I})$ & $(46.8)$ & (16.9) & - & (36.4) & $(53.2)$ & $(46.8)$ & (100.0) \\
\hline
\end{tabular}


Table 1. (Continuation) Distribution of all medical schools acknowledged by MEC and active until December 31, 2017, by inclusion in the study, geographic region, administration type and tuition status.

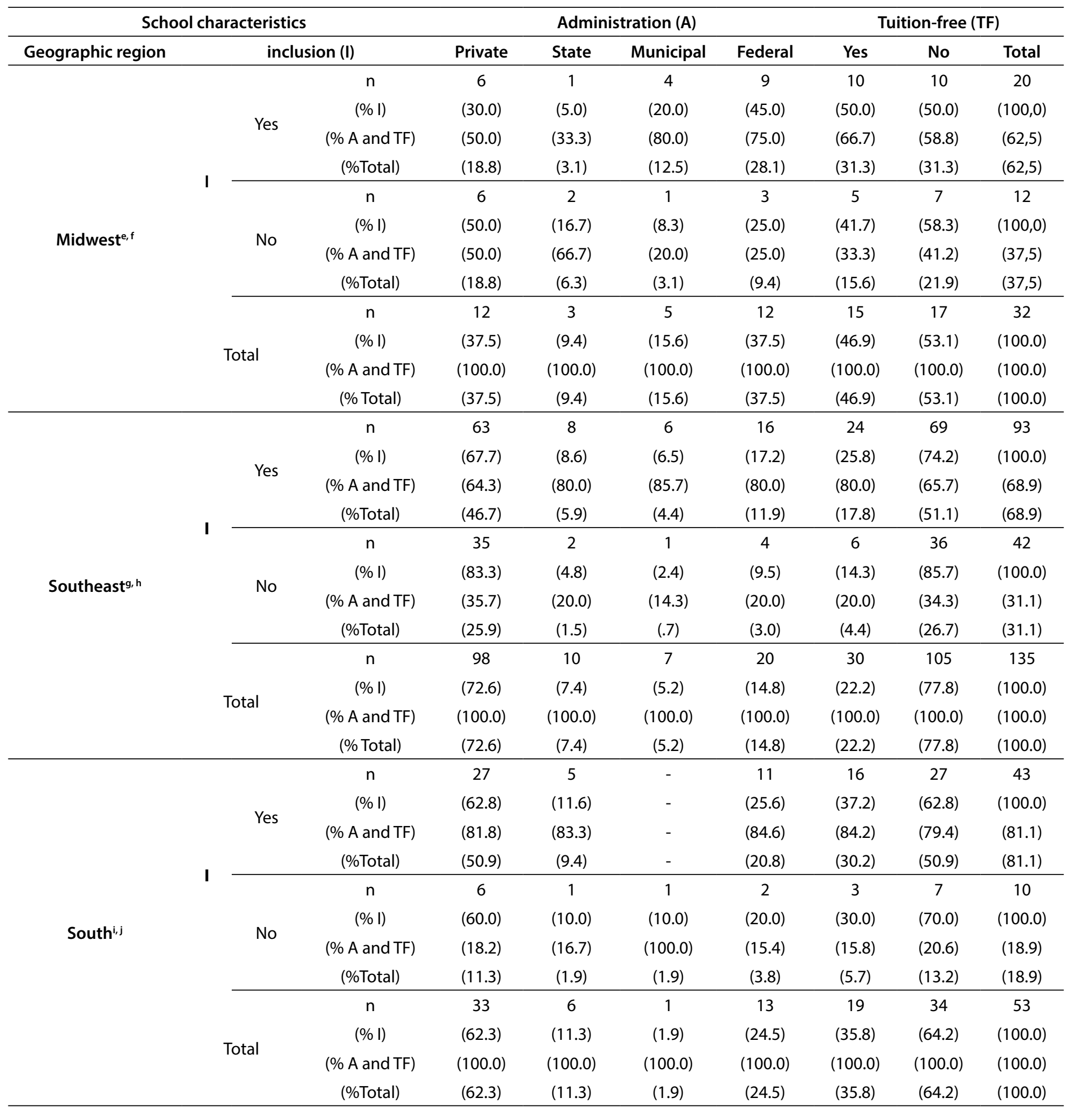


Table 1. (Continuation) Distribution of all medical schools acknowledged by MEC and active until December 31, 2017, by inclusion in the study, geographic region, administration type and tuition status.

\begin{tabular}{|c|c|c|c|c|c|c|c|c|c|c|}
\hline \multicolumn{4}{|c|}{ School characteristics } & \multicolumn{4}{|c|}{ Administration (A) } & \multicolumn{3}{|c|}{ Tuition-free (TF) } \\
\hline Geographic region & & & on (I) & Private & State & Municipal & Federal & Yes & No & Total \\
\hline \multirow{12}{*}{ Total $^{k, l, m, n, o, p, q, r}$} & \multirow{8}{*}{ I } & \multirow{4}{*}{ Yes } & $\mathrm{n}$ & $\mathrm{n}$ & 128 & 24 & 11 & 59 & 83 & 139 \\
\hline & & & $(\% \mathrm{I})$ & $(57.7)$ & $(10.8)$ & (5.0) & $(26.6)$ & (37.4) & $(62.6)$ & (100.0) \\
\hline & & & (\% $\mathrm{A}$ and $\mathrm{TF})$ & $(67.0)$ & $(66.7)$ & (78.6) & $(72.0)$ & $(70.3)$ & $(67.8)$ & $(68.7)$ \\
\hline & & & (\%Total) & (39.6) & (7.4) & (3.4) & $(18.3)$ & $(25.7)$ & $(43.0)$ & $(68.7)$ \\
\hline & & \multirow{4}{*}{ No } & $\mathrm{n}$ & $\mathrm{n}$ & 63 & 12 & 3 & 23 & 35 & 66 \\
\hline & & & $(\% \mathrm{I})$ & $(62.4)$ & (11.9) & (3.0) & $(22.8)$ & $(34.7)$ & $(65.3)$ & $(100.0)$ \\
\hline & & & (\% A and TF) & (33.0) & (33.3) & $(21.4)$ & $(28.0)$ & $(29.7)$ & $(32.2)$ & (31.3) \\
\hline & & & (\%Total) & (19.5) & (3.7) & (.9) & (7.1) & $(10.8)$ & $(20.4)$ & (31.3) \\
\hline & \multirow{4}{*}{\multicolumn{2}{|c|}{ Total }} & $\mathrm{n}$ & $\mathrm{n}$ & 191 & 36 & 14 & 82 & 118 & 205 \\
\hline & & & $(\% \mathrm{I})$ & $(59.1)$ & $(11.1)$ & (4.3) & $(25.4)$ & $(36.5)$ & $(63.5)$ & (100.0) \\
\hline & & & (\% A and TF) & (100.0) & $(100.0)$ & $(100.0)$ & $(100.0)$ & (100.0) & (100.0) & (100.0) \\
\hline & & & (\% Total) & $(59.1)$ & (11.1) & (4.3) & $(25.4)$ & (36.5) & (63.5) & (100.0) \\
\hline
\end{tabular}

Abbreviations - MEC: Ministry of Education; I: inclusion; A: type of administration; TF: tuition-free.

Observation: Analyses performed with Pearson's $X^{2}$.

${ }^{a}$ North Region by inclusion and administration: $\mathrm{X}^{2}(3)=2.2, \mathrm{p}=.53$ ( 6 cells with count $<5$ ).

${ }^{\mathrm{b}}$ North Region by inclusion and tuition status: $\mathrm{X}^{2}(1)=.87, \mathrm{p}=.352$ ( 2 cells with count $<5$ ).

c Northeast Region by inclusion and administration: $X^{2}(2)=1.79, p=.41$.

${ }^{\mathrm{d}}$ Northeast region by inclusion and tuition status: $X^{2}(1)=1.35, p=.246$.

e Midwest region by inclusion and administration: $X^{2}(3)=3.34, p=.34$ ( 6 cells with count $<5$ ).

${ }^{\mathrm{f}}$ Midwest region by inclusion and tuition status: $\mathrm{X}^{2}(1)=.21, \mathrm{p}=-.647$.

${ }^{g}$ Southeast region by inclusion and administration: $X^{2}(3)=3.62, p=.305$ ( 6 cells with count $<5$ ).

${ }^{\mathrm{h}}$ Southeast region by inclusion and tuition status: $X^{2}(1)=2.22, p=.136$.

i South region by inclusion and administration: $X^{2}(3)=4.43, p=.218$ ( 6 cells with count $<5$ ).

'South region for inclusion and tuition status: $\mathrm{X}^{2}(1)=.18, \mathrm{p}=.699$.

${ }^{k}$ Inclusion by region: $\mathrm{X}^{2}(4)=8.08, \mathrm{p}=.89$.

' Inclusion by administration: $\mathrm{X}^{2}(3)=1.36, \mathrm{p}=.715$.

${ }^{\mathrm{m}}$ Inclusion by tuition status: $\mathrm{X}^{2}(1)=.224, \mathrm{p}=.636$.

${ }^{n}$ Number of schools included and not included: $X^{2}(1)=45,328, p=.000$.

${ }^{\circ}$ Administration by region in all schools: $X^{2}(12)=40.03, p=.000$.

${ }^{\mathrm{p}}$ Tuition status by region in all schools: $\mathrm{X}^{2}(4)=24.72, \mathrm{p}=.000$.

${ }^{q}$ Administration by region in the included schools: $X^{2}(12)=29.97, p=.03$; and in those not included: $X^{2}(12)=22.84, p=.029$.

r Tuition status by region in those included: $X^{2}(4)=11.48, p=.022$; and those not included: $X^{2}(4)=17.77, p=.001$. 
Table 2. Total course load and Community Health course load before clerkship and percentage of this load in relation to the total course load of the included medical schools, acknowledged by MEC and active until December 31, 2017, by geographic region, administration type and tuition status.

\begin{tabular}{|c|c|c|c|}
\hline \multirow[b]{2}{*}{ School characteristics } & \multicolumn{3}{|c|}{ Course load } \\
\hline & $\begin{array}{c}\text { Course } \\
\text { Median }\left(P_{25-75}\right)\end{array}$ & $\begin{array}{l}\text { CH before clerkship } \\
\text { Median }\left(P_{25-75}\right)\end{array}$ & $\begin{array}{l}\text { \% } \mathrm{CH} \text { before clerkship/course } \\
\text { Median }\left(\mathrm{P}_{25-75}\right)\end{array}$ \\
\hline North $(n=20)$ & $8,535.0(7,815.0-8,802.5)$ & $505.0(375.0-720.0)$ & $6.0(4.4-8.6)$ \\
\hline Northeast $(n=46)$ & $7,980.0(7,564.5-8,721.5)$ & $420.0(276.7-657.00)$ & $4.9(3.3-8.6)$ \\
\hline Southeast $(n=93)$ & $8,375.0(7,673.5-8,910.0)$ & $450.0(294.5-674.0)$ & $5.4(3.3-8.1)$ \\
\hline South $(n=43)$ & $8,205.0(7,673.0-8,704.0)$ & $420.0(300.0-576.0)$ & $5.3(3.5-7.5)$ \\
\hline \multicolumn{4}{|l|}{ Administration ${ }^{d, e, f}$} \\
\hline Private $(n=128)$ & $8,276.0(7,631.0-8,880.7)$ & 480.0 (330.7- 679.2) & $6.0(3.9-8.3)$ \\
\hline Municipal $(n=11)$ & $8,500.0(7,607.0-8,963.0)$ & $576.0(360.0-766.0)$ & $6.8(3.7-10.0)$ \\
\hline \multicolumn{4}{|l|}{ Tuition-free ${ }^{g, h, i}$} \\
\hline Yes $(n=83)$ & $8,205.0(7,660.0-8,785.0)$ & $364.0(285.0-504.0)$ & $4.5(3.4-6.2)$ \\
\hline No $(n=139)$ & $8,280.0(7,607.0-8,903.0)$ & $500.0(336.0-690.0)$ & $6.1(3.9-8.5)$ \\
\hline Total $(n=222)$ & $8,262.5(7,641.7-8,848.5)$ & $440.0(300.0-640.0)$ & $5.4(3.5-7.8)$ \\
\hline
\end{tabular}

Abbreviation - MEC: Ministry of Education; $\mathrm{CH}$ : Community Health; $\mathrm{P}_{25-75}: 25^{\text {th }}$ and $75^{\text {th }}$ percentiles.

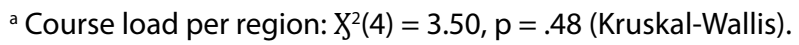

${ }^{\mathrm{b}}$ Community Health course load before clerkship by region: $\mathrm{X}^{2}(4)=2.95, \mathrm{p}=.56$ (Kruskal-Wallis).

' Percentage of Community Health load before clerkship in relation to the course load by region: $X^{2}(4)=2.06, p=.72$ (Kruskal-Wallis).

${ }^{\mathrm{d}}$ Course load by administration: $\mathrm{X}^{2}(3)=4.34, \mathrm{p}=.23$ (Kruskal-Wallis)

${ }^{e}$ Community health course load before clerkship by administration: $X^{2}(3)=11.48, p=.009$ (Kruskal-Wallis).

${ }^{f}$ Percentage of Community Health course load before clerkship in relation to the course load by administration: $X^{2}(3)=11.52, p=.009$ (Kruskal-Wallis).

${ }^{g}$ Course load by tuition-free status: Mann-Whitney $U(U)=5,600.0 . z=-.364, p=.716$.

${ }^{\mathrm{h}}$ Community health workload before clerkship by tuition-free status: $U=4,259.0, z=-3.26, p=.001$.

' Percentage of Community Health load before clerkship in relation to the course load by tuition-free status: $U=4,283.5, z=--3,21, p=.001$. 
Table 3. Theorethical and practical Community Health course loads before clerkship of the included medical schools, acknowledged by MEC and active until December 31, 2017 by region, type of administration and tuition status.

\begin{tabular}{|c|c|c|c|c|c|c|}
\hline \multirow[b]{3}{*}{ School characteristics } & \multicolumn{6}{|c|}{ Community health course load } \\
\hline & \multicolumn{2}{|r|}{ Theoretical $^{a, b, c}$} & \multicolumn{2}{|r|}{ Practical ${ }^{\mathrm{d}, \mathrm{e}, \mathrm{f}}$} & \multicolumn{2}{|c|}{ Not categorized ${ }^{\mathrm{g}, \mathrm{h}, \mathrm{i}}$} \\
\hline & $\mathbf{n}$ & Median $\left(P_{25-75}\right)$ & $\mathbf{n}$ & Median $\left(\mathbf{P}_{25-75}\right)$ & $\mathbf{n}$ & Median $\left(\mathbf{P}_{25-75}\right)$ \\
\hline \multicolumn{7}{|l|}{ Region } \\
\hline North & 9 & $320.0(257.50-440.0)$ & 9 & $280.0(105.0-470.0)$ & 11 & $440.0(300.0-760.0)$ \\
\hline Northeast & 16 & $202.5(170.2-307.5)$ & 16 & $194.5(118.7-316.0$ & 30 & $420.0(247.5-657.0)$ \\
\hline Midwest & 6 & $190.0(123.5-243.0)$ & 6 & $331.0(130.5-635.0)$ & 14 & $384.0(311.5-592.0)$ \\
\hline Southeast & 49 & $220.0(171.0-280.0)$ & 48 & $153.5(60.0-330.7)$ & 44 & $470.0(334.5-747.0)$ \\
\hline South & 18 & $165.0(119.0-259.5)$ & 18 & $191.0(90.0-327.0)$ & 25 & $420.0(294.0-652.0)$ \\
\hline \multicolumn{7}{|l|}{ Administration } \\
\hline Private & 49 & $220.0(168.5-330.0)$ & 48 & $237.0(85.5-430.5)$ & 79 & $480.0(340.0-690.0)$ \\
\hline State & 10 & $197.5(143.7-300.0)$ & 10 & $148.5(80.7-283.2)$ & 14 & $300.0(277.5-670.0)$ \\
\hline Municipal & 4 & $98.0(80.7-317.0)$ & 4 & $392.5(52.5$ - 667.2) & 7 & $576.0(360.0-766.0)$ \\
\hline Federal & 35 & $225.0(160.0-270.0)$ & 35 & $165.0(90.0$ - 270.0) & 24 & $354.0(255.0-565.5)$ \\
\hline \multicolumn{7}{|l|}{ Tuition-free } \\
\hline Yes & 45 & $220.0(153.5-270.0)$ & 45 & $160.0(96.0-267.5)$ & 38 & $337.5(270.0-595.5)$ \\
\hline No & 53 & $217.0(162.5-330.0)$ & 53 & $237.0(85.5-446.5)$ & 86 & $480.0(360.0-690.0)$ \\
\hline Total & 98 & $218.5(159.0-278.0)$ & 98 & $180.0(90.0-346.5)$ & 124 & $436.5(300.0-663.7)$ \\
\hline
\end{tabular}

Abbreviation - MEC: Ministry of Education; $n$ : number of schools in absolute frequency; $P_{25-75}: 25^{\text {th }}$ and $75^{\text {th }}$ percentiles.

a By region: $X^{2}(4)=10.22, p=.037$ (Kruskal-Wallis).

${ }^{\mathrm{b}}$ By administration: $\mathrm{X}^{2}(3)=3.82, \mathrm{p}=.28$ (Kruskal-Wallis).

c By tuition-free status: Mann-Whitney $\mathrm{U}(\mathrm{U})=1,97.0, \mathrm{z}=-.68, \mathrm{p}=.496$.

${ }^{\mathrm{d}}$ By region: $\mathrm{X}^{2}(4)=2.73, \mathrm{p}=.604$ (Kruskal-Wallis)

e By administration: $X^{2}(3)=1.71, p=.635$ (Kruskal-Wallis).

${ }^{f}$ By tuition-free status: $U=1,005.0, z=-1.194, p=.233$.

9 By region: $X^{2}(4)=2.74, p=.603$ (Kruskal-Wallis).

${ }^{\mathrm{h}}$ By administration: $\mathrm{X}^{2}(3)=8.12, \mathrm{p}=.044$ (Kruskal-Wallis).

' By tuition status: $\mathrm{U}=1,129.0, \mathrm{z}=-2.738, \mathrm{p}=.006$. 
Table 4. Course load of epidemiology and statistics and occupational health before clerkship (included in the calculation of the total community health course load) by geographic region, administration type and tuition status in the included medical schools acknowledged by MEC and active until December 31, 2017.

\begin{tabular}{|c|c|c|c|c|}
\hline \multirow[b]{3}{*}{ School characteristics } & \multicolumn{4}{|c|}{ Course load of } \\
\hline & \multicolumn{2}{|c|}{ Epidemiology and statistics ${ }^{a, b, c}$} & \multicolumn{2}{|c|}{ Occupational health ${ }^{d, e, f}$} \\
\hline & $\mathbf{n}$ & Median $\left(\mathrm{P}_{25-75}\right)$ & n & Median $\left(\mathrm{P}_{25-75}\right)$ \\
\hline North & 13 & $105.0(70.0-162.5)$ & 5 & $60.0(35.0-70.0$ \\
\hline Northeast & 28 & $90.0(60.0-120.0)$ & 14 & $45.0(38.5-60.0)$ \\
\hline Southeast & 65 & $80.0(60.0-120.0)$ & 30 & $40.0(32.2-72.0)$ \\
\hline South & 26 & $102.5(68.0-120.0)$ & 12 & $34.5(30.0-58.5)$ \\
\hline \multicolumn{5}{|l|}{ Administration } \\
\hline Private & 77 & $80.0(60.0-120.0)$ & 37 & $40.0(34.5-66.0)$ \\
\hline \multicolumn{5}{|l|}{ Tuition-free } \\
\hline Yes & 60 & $90.0(72.0-120.0)$ & 24 & $47.5(31.0-60.0)$ \\
\hline No & 82 & $80.0(60.0-120.0)$ & 39 & $40.0(33.0-60.0)$ \\
\hline Total & 124 & $88.0(60.0-120.0)$ & 63 & $40.0(33.0-60.0)$ \\
\hline
\end{tabular}

Abbreviations: $n$ : number of schools in absolute frequency; $P_{25-75}-25^{\text {th }}$ and $75^{\text {th }}$ percentiles

a By region: $X^{2}(4)=6.63, p=0.157$ (Kruskal-Wallis).

${ }^{\mathrm{b}}$ By administration: $\mathrm{X}^{2}(3)=5.05, \mathrm{p}=0.168$ (Kruskal-Wallis).

' By tuition-free status: Mann-Whitney-U $(U)=2,060.0, z=-1.657, p=0.098$.

${ }^{\mathrm{d}}$ By region: $\mathrm{X}^{2}(4)=5.25, \mathrm{p}=0.263$ (Kruskal-Wallis).

e By type of administration: $\mathrm{X}^{2}(3)=2.58, \mathrm{p}=0.46$ (Kruskal-Wallis).

${ }^{f}$ By tuition-free status: $U=448.0, z=-0.286, p=0.775$.

Table 4 shows the EB and $\mathrm{OH}$ CLs by geographic region, administration type and tuition status. There was no difference in any of the studied variables.

\section{DISCUSSION}

Our study included $68.7 \%$ of MS acknowledged by MEC and active until December 31, 2017. We found a higher number of private and non-tuition-free schools in Brazil, which was especially higher in the southeast region. We also found that there is a higher proportion of private and non-tuitionfree schools in the South and Southeast regions and a more balanced proportion between tuition-free and non-tuitionfree schools in the other regions. This greater balance, perhaps, could partly be justified by the federal MS expansion from 2013 to 2015, resulting from the Mais Médicos (More Doctors) Program, implemented in $2013^{20}$. During this period, 30 schools were created: 13 in the Northeast, 3 in the North, 4 in the Midwest, 5 in the Southeast and 5 in the South region ${ }^{20}$.

Another finding was a higher $\mathrm{CH} C L$ before clerkship in non-tuition-free schools, however, we could not raise a plausible hypothesis for this finding.

Also, the theoretical $\mathrm{CH} \mathrm{CL}$ before clerkship was higher in the Northern region. Nevertheless, it is noteworthy that only nine schools located in that region made their $C L$ available in a discriminatory manner, which may have led to a bias in this analysis, since, when considering the total $\mathrm{CHCL}$, there was no difference between the regions.

In the literature, we identified national cases as case studies or reports, among them, one carried out in three universities in the state of Paraná ${ }^{11}$, one about the Universidade Estadual de Londrina $(U E L)^{22}$ and its curriculum transformation process and one about the Faculdade de Medicina de Marilia ${ }^{23}$ curriculum. There are also studies about the Universidade Estadual do Ceará ${ }^{18,24}$ curriculum. However, due to the lack of recommendations for the $\mathrm{CH} \mathrm{CL}$ limits before clerskhip in the DCN and of comprehensive national studies covering most Brazilian schools, it was not possible to compare our findings with national data. This gap was the main motivation for carrying out our study. 
We found international recommendations and studies that allowed comparisons.

The Cuban Ministry of Education establishes that the medical course curriculum must include a $C L$ of 1,242.0 hours before clerkship aimed at the subjects analyzed in our study ${ }^{25,26}$. This value is more than twice the $75^{\text {th }}$ percentile $\left(P_{75}\right)$ obtained in our study.

In the University of Toronto medical course, in Canada, the period before clerkship lasts two years ${ }^{27}$, in which the $\mathrm{CH}$ $\mathrm{CL}$ is 328.0 hours $^{28}$. This value is close to the $25^{\text {th }}$ percentile $\left(P_{25}\right)$ in our study. Reviewing the curriculum progress throughout 10 years before clership, it was verified that the $\mathrm{CHCL}$ redistribution over the two years, without altering the total $\mathrm{CL}$, resulted in better academic outcomes ${ }^{28}$.

Some other international studies mention the $\mathrm{CL}$, but, they do not specify whether it is the total course load or the CL before clerkship. A Catalan study ${ }^{29}$, which included four MS, found a variation between 1.5 and 12 credits in the CLs. In the European Credit Transfer and Accumulation System, each credit is equivalent to 25 to 30 hours $^{30}$. Thus, the $\mathrm{CHCL}$ in the Catalan study ranged from 37.5 to 360.0 hours ${ }^{29}$, a value below the $P_{25}$ found in our study.

A study with $16 \mathrm{MS}$ from six Eastern European countries found a variation from 235.0 to 615.0 hours in the $\mathrm{CH} \mathrm{CLs}{ }^{31}$. Another study with $32 \mathrm{MS}$ from 18 countries in Europe found a variation from 18.5 to 500.0 hours in the $\mathrm{CLs}^{32}$. Although it was not possible to know whether the CLs included the clerkship, of the $16 \mathrm{MS}$ in the Eastern European study ${ }^{31}, 13$ had a CH CL that ranged between the $\mathrm{P}_{25-75}$ in our study and two had a CL below the $\mathrm{P}_{25}$ in our study. As for the study with 32 European schools ${ }^{32}$, in 10 , the $\mathrm{CHCL}$ was between the $\mathrm{P}_{25-75}$ in our study and, in 22, it was below the $P_{25}$.

In Great Britain, in 2008, among 29 of 31 British schools, the mean percentage of $\mathrm{CH}$ training in relation to the total CL was $13.0 \%$, ranging from 3.4 to $20.0 \%$. The authors did not specify whether it was before clerkship or throughout the course $^{33}$. This average is well above the the median found in our study; however, we emphasize that it can represent the $\mathrm{CHCL}$ of the entire course, including clerkship.

As for the $\mathrm{OH} \mathrm{CL}$, in a study in $\mathrm{UK}^{34}$, the content ranged from zero to more than 6 hours a week, while in other in Mexico $^{35}$ with $35 \mathrm{MS}$, the $\mathrm{OH}$ discipline lasted one semester and the $\mathrm{CL}$ varied from 1 to 8 hours/week. In the study with 16 Eastern European schools ${ }^{31}$, the $\mathrm{CL}$ of $\mathrm{OH}$ varied from 30.0 to 165.0 hours; comparing the $\mathrm{CL}$ of these schools in relation to the $C L$ found in our study, it was below the $\mathrm{P}_{25}$ in one school, above the $P_{75}$ in ten schools and between the $P_{25-75}$ in four schools. In the study with 32 European schools ${ }^{32}$, the $C L$ ranged from zero to 105.0 hours, five of which were below the $P_{25}$ of our study, four above the $P_{75}$ and three between the $P_{25-75^{\circ}}$.

Regarding the EB CL, it was 120.0 hours in $\mathrm{Cuba}^{26}$, which is equivalent to the $\mathrm{P}_{75}$ in our study. In Eastern European ${ }^{31}$, this $C L$ ranged from 75 to 180 , with the $C L$ of four MS above the $P_{75}$ in our study and the remaining 11 between the $P_{25-75}$. In the study with 32 European schools ${ }^{32}$, the $C L$ ranged from 7.0 to 225.0 hours, with the $C L$ of 11 schools below the $P_{25}$ of our study, five above the $P_{75}$ and seven between the $P_{25-75^{\circ}}$.

The limitations of our study include the impossibility to differentiate the theoretical and practical $C L$ in almost half of the included schools, as well as the impossibility of including schools that did not clarify the $\mathrm{CL}$ intended for $\mathrm{CH}$ in their integrated modules. Although the curricular integration is recommended, ideally, the $C L$ intended for each area should be specified, aiming to provide objective parameters of comparison. Another limitation was the analysis of data only available in the internet.

In order to have a better understanding of $\mathrm{CH}$ teaching, we suggest further studies that analyze the schools' politicalpedagogical concept and current of thought that support the $\mathrm{CH}$ teaching, the distribution of $\mathrm{CH}$ throughout the course, its contents and the teaching- learning strategies and settings, including students' assessment. For reaching this purpose, it would be necessary a detailed analysis of the schools' politicalpedagogical projects and teaching-learning plans, associated with interviews with managers, teachers and students.

\section{CONCLUSIONS}

The schools included in the study were representative in terms of type of administration and tuition status in each geographic region.

There was great variability regarding the $\mathrm{CH} C L$ median before clerkship, as well as its percentage in relation to the $\mathrm{CL}$ of the total course, which were higher in non-tuition-free schools, which are in higher proportion in the Southeast and South regions.

The $\mathrm{EB}$ and $\mathrm{OH}$ contents are similar by region, type of administration and tuition status.

\section{AUTHORS' CONTRIBUTION}

Sofia Romay Oliveira participated in the project design, data collection and analysis and drafting of the manuscript, which was the term paper that she presented as the undergraduate medical course requirement at UFSC. Athos Paulo Santos Martini participated in the project design, data collection and analysis and drafting and review of the manuscript. Suely Grosseman participated as Ms. Oliveira's advisor and in the project creation, data collection and analysis and drafting and review of the manuscript. 


\section{CONFLICTS OF INTEREST}

The authors declare no conflicts of interest.

\section{SOURCES OF FUNDING}

The authors declare no external sources of funding for this research.

\section{REFERENCES}

1. Horton R. A new epoch for health professionals' education. Lancet. 2010;376(9756):1875-7.

2. Tambellini AT, Câmara VM. A temática saúde e ambiente no processo de desenvolvimento do campo da saúde coletiva: aspectos históricos, conceituais e metodológicos. Cien Saude Colet 1998;3(2):47-59.

3. Grosseman S, Patrício ZM. Do desejo à realidade de ser médico. Florianópolis: Editora da UFSC; 2004.

4. Almeida MJ. A educaçäo médica e as atuais propostas de mudança: alguns antecedentes históricos. Rev Bras Educ Med. 2001;25(2):42-52 [acesso em 24 out 2018]. Disponível em: http://www.educacaomedica. org.br/UserFiles/File/2001/Volume25 2/educacao_medica.pdf.

5. Gibbon W. Medical schools for the health-care needs of the 21 st century. Lancet. 2007;369(9580):2211-3.

6. Johnson I, Donovan D, Parboosingh J. Steps to improve the teaching of public health to undergraduate medical students in Canada. Acad Med. 2008;83(4):414-8.

7. Tyler IV., Hau M, Buxton JA, Elliott LJ, Harvey BJ, Hockin JC, et al. Canadian medical students' perceptions of public health education in the undergraduate medical curriculum. Acad Med. 2009;84(9):1307-12.

8. Jin H, Dong G, Zou L, Shen X, Li D. History and status quo of higher public health education in China. Public Health Rev. 2020;41:1-16.

9. Luque-Fernández MA, Calduch EN. Education in public health, epidemiology and biostatistics in Spain from a global and comparative perspective. Gac Sanit. 2019;33(6):502-3.

10. Bell C, Simmons A, Martin E, McKenzie C, McLeod J, McCoombe S. Competent with patients and populations: Integrating public health into a medical program. BMC Med Educ. 2019;19(1):1-9.

11. Gillam S, Rodrigues V, Myles P. Public health education in UK medical schools: towards consensus. J Public Healh. 2016;38(3):522-5.

12. Nagesh NM, Giurca BC. Empowering undergraduate students to pioneer public health education: a call for action. Perspect Public Health. 2019;139(4):179-80.

13. Ofori-Adjei $D$. Changing landscape of public health and medical education curriculum. Ghana Med J. 2018;52(3):115-115.

14. Brasil. Resolução CNE/CES no 4, de 7 de novembro de 2001. Institui Diretrizes Curriculares Nacionais do Curso de Graduação em Medicina. Diário Oficial da União; 9 nov 2001. Seção 1, p. 38.

15. Brasil. Resolução CNE/CES n 3, de 20 de junho de 2014. Institui Diretrizes Curriculares Nacionais do Curso de Graduação em Medicina. Diário Oficial da União; 23 jun. 2014. Seção 1, p. 8-11.

16. Lima-Gonçalves E. Médicos e ensino da medicina no Brasil. São Paulo: Edusp; 2002.

17. BRASIL. e-MEC: Instituições de educação superior e cursos cadastrados [acesso em 14 ago 2018]. Brasília: Ministério da Educação; 2007. Disponível em: http://emec.mec.gov.br.

18. Oliveira JAA, Jorge MSB, Silva MGC, Pinto DM, Pinto FJM. A saúde coletiva na formação dos discentes do curso de Medicina da Universidade Estadual do Ceará, Brasil. Rev Bras Educ Med. 2011;35(3):398-404.
19. Conselho Federal de Medicina. Resolução no 1.488/98, de 11 de fevereiro de 1998. Normas específicas para médicos que atendam o trabalhador. Diário Oficial da União; 6 mar 1998. Seção I, p. 150.

20. Cyrino EG, de Sordi MRL, Mendes GSCV, Luna WF, Mendonça CS, Alexandre FLF, et al. Mapeamento das características da implantação de novos cursos de Medicina em universidades federais brasileiras. Rev Panam Salud Publica. 2020 Oct;44:e117 [acesso em 22 out 2020]. Disponível em: https://iris.paho.org/handle/10665.2/52802.

21. de Campos JJB, Elias PEM, Cordoni Junior L. O ensino da saúde coletiva na graduação médica: estudo de caso em três universidades do Paraná. Sao Paulo Med J. 2009;127(6):335-41.

22. de Campos JJB, Elias PEM. Universidade Estadual de Londrina: reflexões iniciais. Rev Bras Educ Med. 2008;32(2):149-59.

23. Feuerwerker LCM. Além do discurso de mudança na educação médica: processos e resultados. São Paulo: Hucitec; 2002.

24. Gomes NN. Avaliação da formação de profissionais médicos de uma universidade pública em Fortaleza-CE [dissertação]. Fortaleza: Universidade Estadual do Ceará; 2014.

25. Valdés JV, Sacasas JF. Las asignaturas de salud pública en las políticas de formación para la carrera de medicina. Rev Cuba Salud Pública. 2012:38(3):383-92 [acesso em 14 jul 2020]. Disponível em: http://scielo. sld.cu/scielo.php?script=sci_arttext\&pid=S0864-34662012000300005.

26. Aguilera EAM, Díaz NT, Sacasas JF, Gómez MP, Figueredo SS, Cobelo JMD. Cronología de los mapas curriculares en la carrera de Medicina. Educ Med Super. 2015;29(1)93-107 [acesso em 16 jul 2020]. Disponível em: $\quad$ http://scielo.sld.cu/scielo.php?script=sci_arttext\&pid=S086421412015000100010\&lng=es.

27. Newman A. The New Toronto Medical Curriculum. Biochem Educ. 1993;21(4):170-9 [acesso em 16 jul 2020]. Disponível em: https://www. sciencedirect.com/science/article/pii/030744129390085E.

28. Johnson IL, Scott FE, Byrne NP, MacRury KA, Rosenfield J. Integration of community health teaching in the undergraduate medicine curriculum at the University of Toronto. Am J Prev Med. 2011;41 (4 Suppl 3):S176-80. doi: 10.1016/j.amepre.2011.06.003.

29. Obradors-Rial N, Segura-Benedicto A. La salud pública en las facultades de medicina y escuelas de enfermería de Cataluña: la visión del alumnado. Educ Med. 2010;13(2):113-22.

30. European Communities. ECTS Users' Guide. 2009 [acesso em 14 out 2018]. Disponível em: http://ec.europa.eu/dgs/education_culture/repository/ education/tools/docs/ects-guide_en.pdf.

31. Likic R, Dusek T, Horvat D. Analysis and prospects for curricular reform of medical schools in Southeast Europe. Med Educ. 2005;39(8):833-40. doi: 10.1111/j.1365-2929.2005.02228.x.

32. Dusek T, Bates T. Analysis of European medical schools'teaching programs. Croat Med J. 2003;44(1):26-31 [acesso em 17 out 2018]. Disponível em: http://www.ncbi.nlm.nih.gov/pubmed/12590425.

33. Harding A, Rosenthal J, Al-Seaidy M, Gray DP, McKinley RK. Provision of medical student teaching in UK general practices: a cross-sectional questionnaire study. Br J Gen Pract. 2015; 65(635):e409-17. doi: 10.3399/ bjgp15X685321

34. Williams N, Wynn PA, Whitaker S. Undergraduate occupational medicine tuition in UK schools of medicine. Occup Med (Chic III). 2011;61(3):152-6. doi: 10.1093/occmed/kqr010.

35. Sánchez-Román FR, Medina-Figueroa AM, Rangel-Zertuche RA, SánchezRamos A. Enseñanza de medicina del trabajo en el pregrado de las escuelas de medicina en México. Salud Publica Mex. 2009;51(1):97-103. 